\title{
An investigation of the relationship between self-serving attributions and corporate governance
}

\author{
Antônio Thadeu Mattos da Luz ${ }^{\dagger}$ \\ FUCAPE Business School \\ Marcelo Sanches Pagliarussi ${ }^{\Omega}$ \\ FUCAPE Business School \\ Arilda Magna Campanharo Teixeira ${ }^{¥}$ \\ FUCAPE Business School \\ Ézio Carlos Baptista ${ }^{\Psi}$ \\ FUCAPE Business School
}

\begin{abstract}
Studies on the management of operational risk in financial organizations have predominantly utilized quantitative and probabilistic approaches. Such approaches provide managers with a way to estimate the probability of operational failure occurring but do not provide insights with regard to specific managerial actions that can be taken to avoid the occurrence of such failure. Results of our study of the processes of a large Brazilian banking institution suggest that $\mathrm{HRO}$ theories can make an important contribution to the effective management of operational risk. Understanding the underlying causal mechanisms that contribute to operational failures makes it possible to take steps to manage them and to reduce the probability that they will occur. In addition to suggesting a new approach to the management of operational risk in financial institutions, the study tested HRO theory in a new sector. The results clearly demonstrate that HRO concepts are relevant in financial institutions, broadening the scope of applicability of this theory.
\end{abstract}

Keywords: high reliability organizations; operational risk management; financial institutions.

Received in 12/09/2008; revised in 06/08/2209; accept in 08/02/2009.

Corresponding authors*:

$\uparrow$

Master Student the FUCAPE

Business School

Address: Rua Genserico

Encarnação, 50, Mata Da Praia,

Vitória-ES - Brazil

CEP: $29065-420$

e-mail:atmluz@terra.com.b

Telephone: (27) 3225-8318

$\Omega$ Professor in FUCAPE Business

School

Address: Av. Fernando Ferrari,

1358, Boa Vista, Vitória-ES -

Brazil - CEP: 29075-505,

e-mail:marcelo@fucape.br

Telephone: (27) 4009-4444
$¥$ Professor in FUCAPE Business

School

Address: Av. Fernando Ferrari,

1358, Boa Vista, Vitória-ES -

Brazil - CEP: 29075-505,

e-mail:arildat@fucape.br

Telephone: (27) 4009-4444
$\Psi$

Professor in FUCAPE Business School

Address: Av. Fernando Ferrari,

1358, Boa Vista, Vitória-ES -

Brazil - CEP: 29075-505,

e-mail: ezio@fucape.br

Telephone: (27) 4009-4444

Editor's note: This paper was accepted by Antonio Lopo Martinez 


\section{INTRODUCTION}

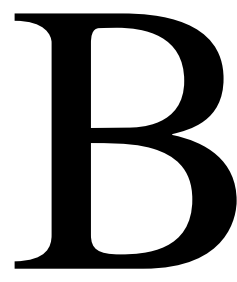

razilian companies listed on the São Paulo Stock Exchange (Bovespa - Bolsa de Valores de São Paulo) annually publish a set of documents containing objective and subjective information about their performance in the preceding year. These documents are known as Annual Information (IAN - Informações Anuais) andStandard Financial Reports (DFP - Demonstrações Financeiras Padronizadas).

The Standard Financial Reports contain two distinct sections. One is the mandatory section comprising the financial statements. The other, whose publication is strongly recommended by the Brazilian Securities Commission (Comissão de Valores Mobiliários, or CVM), has a narrative and textual nature. This last section contains the Management Report.

The Management Report usually explains and clarifies the firm's strategic actions and goals. In this sense, this document offers an opportunity to demonstrate compliance with precepts of good corporate governance.

Corporate governance can be viewed through many different angles. The Brazilian Corporate Governance Institute (IBGC, 2004, p. 6) defines it as:

\footnotetext{
... the system through which corporations are run and monitored, involving the relationship among shareholders, the board, executive officers and auditors. Good corporate governance practices aim at increasing a corporation's value, allowing easier access to sources of capital and contributing to its continuity.
}

The quality of corporate governance practices adopted by corporations is a complex and multidimensional construct. This complexity results in considerable empirical challenges to proxy it. In Brazil, one overall evaluation of corporate governance quality is the "seal" attributed by Bovespa to listed companies that voluntarily comply with differentiated corporate governance practices.

The basic question about corporate governance is how suppliers of finance to firms assure themselves of a return on their investment. So, corporate governance mechanisms are economic and legal institutions that can be altered through the political process (Shleifer \& Vishny, 1997).

One of the basic principles guiding corporate governance is transparency, which is defined by the Brazilian Corporate Governance Institute (IBGC, 2004, p. 9) as:

\footnotetext{
More than the "duty or obligation to inform", management should cultivate the "desire to inform", knowing that good internal and external communication, particularly when spontaneous, sincere and swift, begets an atmosphere of trust, both internally and in the relationship with other parties. Communication should not be restricted to financial and economical performance only, but should also encompass other factors (including intangible ones) that drive a firm's actions and lead to the creation of value.
}

Even though the narrative sections are rich and important in informational terms, the fact that they are also less regulated offers managers opportunities to introduce a favorable bias in their considerations (Clatworthy \& Jones, 2003). Such a bias is usually observed as a pattern of attributions: the organization assigns favorable effects to causes internal to the organization and blames unfavorable effects on external causes. Such asymmetric distribution of causality is commonly called self-serving attribution. It allows managers to take credit for successes and avoid blame for failures. As such, it can be regarded as advantageous for the organization (Aerts, 2005). 
Previous empirical studies in the areas of psychology (Schlenker, 1980), organizational research (Bettman \& Weitz, 1983; Staw, Mckechnie \& Puffer, 1983; Salancik \& Meindl, 1984, Clapham \& Schwenk, 1991; Tsang, 2002 and Clatworthy \& Jones, 2003) and accounting (Aerts, 1994, 2001, and 2005) have documented the propensity to attribute positive effects to an organization's internal actions (plant modernization, better controls or management, etc.) in narrative sections, such as increased profits or revenues. Also, negative effects, such as losses or declining revenues, are usually attributed to external causes (inflation, government interference, foreign exchange conditions, etc.).

By and large, research on the use of self-serving attributions is based on psychological theories that postulate either motivational or informational explanations for this organizational behavior. The motivational theory is associated with retrospective rationality and egodefensive behavior, observed in situations of unfavorable outcomes (Staw, 1980; Bettman \& Weitz, 1983). An informational explanation has been derived either from bounded rationality premises or from attributional principles of discounting and augmentation (Bettman \& Weitz, 1983; Tsang, 2002; Aerts, 2001).

The motivational explanation is commonly associated with attempts to manage the corporate image (Staw et al., 1980; Salancik \& Meindl, 1984). The informational explanation, in turn, is based either on biased internal information processing capabilities (Miller \& Ross, 1975) or on other reasoning processes related to the interpretation of environmental events (Kelley, 1971; Huff \& Schwenk, 1990).

Studies connecting corporate governance with a firm's value and with disclosure of accounting variables present in financial statements can be found with reasonable frequency in the literature (Galdi \& Lopes, 2007). On the other hand, studies investigating possible relationships between different levels of corporate governance and contents of narrative sections of reports are not so easily found. Considering the importance given to informational issues in corporate governance, it seems reasonable to expect such connections.

The present work is the first to explore the connections between the use of self-serving attributions in the justification of organizational performance and corporate governance. This work is an attempt to investigate the theoretical linkage between corporate governance levels, as denoted by the Bovespa differentiated market seal, and causal attributions in the narrative section of annual reports. We expect that companies with certified good governance practices will show lower levels of self-serving attributions in their annual report narrative sections.

A sample of 385 annual reports was content analyzed in order to test our hypotheses. Taken together, the results of the tests for the three hypotheses show that companies in the sample use self-serving attributions in their reports, regardless of the corporate governance seal given them by Bovespa. Also, companies which have better corporate governance show a $34 \%$ greater chance of attributing good news to internal causes, and paradoxically, though less significantly, of attributing bad news also to internal causes. However, an analysis of the percentage of annual reports dedicated to each attributional instance shows no significant differences between companies belonging to differentiated listing segments and companies that belong to the traditional exchange segment.

\subsection{Corporate Governance}

The strong movement towards the separation of firms management from ownership observed during the Industrial Revolution of the eighteenth century brought about a heightened risk of capital expropriation by managers and led to the hiring of independent auditors in order to evaluate management's actions (Imhoff, 2003). 
An important aim of corporate governance is precisely to deal with the ways in which suppliers of financial resources to firms assure themselves of getting a return on their investments (Shleifer, Vishny, 1997).

Jensen and Meckling (1976) define firms as a complex set of implicit and explicit contracts that organize and regulate the relationship between the various interested parties. This proposition, known as the agency theory, is frequently used in discussions about corporate governance. The agency relationship is a contract where a certain party (the principal) bestows on another (the agent) prerogatives to work or act on its behalf, and involves authority delegation. The agent will not always act according to the best interests of the principal, a situation where the so called agency and transaction costs, involving creation and monitoring of contracts, appears. It is reasoned that as a manager's participation in ownership decreases his interest in taking advantages of non-pecuniary benefits increases. A firm's market value would thus decrease as a consequence of the principal's distrust in agents, the principal suspecting the agents' intentions of expropriating part of the wealth generated by the firm, wealth that should be apportioned to all participants in the firm. This derives from the so-called information asymmetry: the various interested parties do not have or receive all available information equally. The parties try to obtain and reveal only that information they consider beneficial to themselves, hiding the information that might be unfavorable.

Thus, firms with good corporate governance practices should implement mechanisms aimed at diminishing information asymmetry, to minimize transaction costs and provide greater protection to investors (Lopes \& Martins, 2005). The very act of disclosing how much an organization adheres to such practices tends to decrease informational asymmetry and is probably one of the intentions behind formulation of governance indexes and seals of conformity.

\subsection{The Bovespa listing segments for voluntary enhanced corporate governance practices}

The São Paulo Stock Exchange (Bovespa) separates listed companies according to their commitment to the adoption of better corporate governance practices. In the sampled year of 2006, we identified two main segments, the traditional market and differentiated market segments. The differentiated market segment was further subdivided in three groups, called Level 1, Level 2 and New Market.

Each segment represents a different level of corporate governance, starting with the traditional market segment, going through Level 1, Level 2 and New Market, which is the highest level in the differentiated market segment. Companies listed in the differentiated market segment are endowed with a distinctive seal which is widely publicized by the Bovespa.

The demands and commitments a company must meet in order to be listed in a given segment are listed in Table 1. 
Table 1 - Comparison of rules for listing in the different markets of Bovespa.

\begin{tabular}{|c|c|c|c|c|}
\hline & \multirow{2}{*}{$\begin{array}{l}\text { TRADITIONAL } \\
\text { MARKET }\end{array}$} & \multicolumn{3}{|c|}{ DIFFERENTIATED MARKET (Seal) } \\
\hline & & Level 1 & Level 2 & New Market \\
\hline $\begin{array}{c}\text { Minimum Free Float } \\
\text { Shares }\end{array}$ & $\begin{array}{l}\text { No minimum } \\
\text { required. }\end{array}$ & At least $25 \%$ free & At least $25 \%$ free float. & $\begin{array}{l}\text { At least } 25 \% \text { free } \\
\text { float. }\end{array}$ \\
\hline Stock Characteristics & $\begin{array}{l}\text { Allows stock } \\
\text { with and } \\
\text { without voting } \\
\text { rights. }\end{array}$ & $\begin{array}{l}\text { Allows stock with } \\
\text { and without voting } \\
\text { rights. }\end{array}$ & $\begin{array}{l}\text { Allows stock with and } \\
\text { without voting rights (but } \\
\text { with certain additional } \\
\text { rights in the latter case). }\end{array}$ & $\begin{array}{l}\text { Only stock with } \\
\text { voting rights } \\
\text { allowed. }\end{array}$ \\
\hline Board of Directors & $\begin{array}{l}\text { At least three } \\
\text { members } \\
\text { (required by } \\
\text { law). }\end{array}$ & $\begin{array}{c}\text { At least three } \\
\text { members (required } \\
\text { by law). }\end{array}$ & $\begin{array}{l}\text { At least five members, of } \\
\text { whom at least } 20 \% \text { must } \\
\text { be independent. }\end{array}$ & $\begin{array}{l}\text { At least five } \\
\text { members, of } \\
\text { whom at least } \\
20 \% \text { must be } \\
\text { independent. }\end{array}$ \\
\hline $\begin{array}{l}\text { Publication of Financial } \\
\text { Statements according to } \\
\text { International Standards }\end{array}$ & Optional. & Optional. & US GAAP or IFRS. & $\begin{array}{l}\text { US GAAP or } \\
\text { IFRS. }\end{array}$ \\
\hline \multicolumn{5}{|c|}{ Table 1 - Comparison of rules for listing in the different markets of Bovespa (cont.) } \\
\hline & \multirow{2}{*}{$\begin{array}{l}\text { TRADITIONAL } \\
\text { MARKET }\end{array}$} & \multicolumn{3}{|c|}{ DIFFERENTIATED MARKET (Seal) } \\
\hline & & Level 1 & Level 2 & New Market \\
\hline Tag Along Rights & $\begin{array}{l}80 \% \text { for stock } \\
\text { with voting } \\
\text { rights (required } \\
\text { by law). }\end{array}$ & $\begin{array}{l}80 \% \text { for stock with } \\
\text { voting rights } \\
\text { (required by law). }\end{array}$ & $\begin{array}{l}100 \% \text { for stock with } \\
\text { voting rights and } 80 \% \text { for } \\
\text { stock without voting } \\
\text { rights. }\end{array}$ & $\begin{array}{l}100 \% . \text { All stock } \\
\text { has voting rights. }\end{array}$ \\
\hline $\begin{array}{l}\text { Acceptance of Market } \\
\text { Committee Arbitration }\end{array}$ & Optional & Optional & Mandatory & Mandatory \\
\hline
\end{tabular}

Staw $(1980,1983)$ was one of the first authors to introduce the management of public impressions rationale to analyze the textual portion of corporate annual reports. Using the impression management theory that had been previously developed by psychology researchers, Staw (1980) argued that both individuals and organizations strive for rational and goal-oriented behavior. Nevertheless, actions generally fall short of these ideals. This motivates individuals to rationalize or justify their course of action. The farther the results are from the ideal, the greater are the forces that drive the justification process (Staw, 1980). This process involves both self-justification as well as an external form of justification termed impression management (Staw, 1980).

The justification of organizational performance is compulsory for listed firms, which face higher levels of accountability related to the effective use of resources and goal achievement. Moving from the individual to the organizational level, Staw et al. (1983) tested for the presence of self-serving attributions in organizations' reporting of performance information. One of their research goals was to determine whether self-serving attributions are best explained by either an internal form of justification, expressed by the use of defensiveness attributions, or by an external form, which involves the use of enhancing attributions (Staw, et al., 1983). Also, defensive attributions are observed as a pattern of crediting positive events to internal sources and negative events to external factors (Staw et al., 1983). Staw et al. (1983) successfully demonstrated the existence of self-serving attributions in the letter to shareholders, but but unlike they expected, they did not find organizational performance to determine causal attributions 
Bettman and Weitz's (1983) study was centered on the analysis of reasoning patterns in the justification of corporate performance in order to shed light on the nature of self-serving attributions. Letters to shareholders for a sample of corporations were analyzed considering any instance in which a company's performance outcome and its causes were discussed (Bettman \& Weitz, 1983). Bettman and Weitz (1983) developed motivational hypotheses for the use of self-serving attributions based on ego-defensive rationalizations. They also used Kelley's (1971) attributional principles of discounting and augmentation, which involve the search for plausible arguments to explain the occurrence of performance related events, to develop the informational hypotheses for the use of self-serving attributions.

Bettman and Weitz (1983) observed the typical self-serving pattern of attributions in the letter to shareholders, but neither a purely informational nor a purely motivational explanation was supported by these attributions.

Tsang (2002) analyzed the letters to shareholders of 94 firms listed on the Singapore Stock Exchange in 1985, classified as a bad year, and 114 companies in 1994, a good year, in an attempt to replicate Bettman and Weitz's (1983) study. According to Tsang, although Bettman and Weitz's data did not allow them to clearly demonstrate that only one hypothesis prevailed, the informational explanation was strongly supported by his data.

Salancik and Meindl (1984) presented a longitudinal study that examined the reasons given by CEOs to explain their firms' performance in the letter to shareholders over an 18-year period, comparing firms with stable and unstable performance. They observed that, contrary to psychological theories, managers of firms with unstable performance claim responsibility for both positive and negative outcomes more than managers of firms with stable performance do. Managers of firms with unstable performance also seem reluctant to attribute poor performance to uncontrollable environmental events. They argued that this provides evidence that as the lack of real control over organizational outcomes increases, managers of these firms strategically manipulate causal attributions to manage impressions of their control (Salancik \& Meindl, 1984).

However, Salancik and Meindl (1984) also stressed the difficulties associated with the detection of bias in the use of attributions, since the true causes of an event can never be known. Salancik and Meindl (1984, p. 241) suggested that "[...] when the environment's impact is greater, a selective bias will show up as a greater tendency to take credit for positive outcomes."

Clapham and Schwenk (1991) explored whether the use of self-serving attributions represents attempts to manage corporate image. They investigated annual reports from heavily regulated companies with the premise that "[...] attempts at impression management through the use of self-serving attributions would be more readily detected by the regulatory agency and less likely to be effective" (Clapham and Schwenk, 1991 p. 221). Their results (p. 226) showed the same basic pattern of attributions, since they observed that "executives tended to take credit for good outcomes and lay blame on the environment for poor outcomes."

Clatworthy and Jones (2003) motivated their study on the importance and usefulness of accounting narratives. They found that declining performers accentuate the presentation of good news rather than discussing poor financial performance. Clatworthy and Jones' (2003) results buttressed the idea that accounting narratives are an important data source to study the management of corporate image, since they found that companies in general avoid explicit causal attributions. The prevalent attributional strategy observed was to avoid specific blame for bad news. They also argued that improving performers are more assertive in the language they use in their annual reports. 
Aerts (2005) treated the capital market context as a critical variable to discern situations of strong and weak motivational influences on the use of self-serving attributions. His study explored the effect of attributional statements' thematic content nature on the strength of the attributional bias. The nature (cost, income, revenue, etc.) and measurement level (group, corporate, divisional) of the explained effect and the knowledge of domainspecific jargon and related inference rules are deemed to be important in the interpretation of self-serving attributions (Aerts, 2005).

Results from Aerts' (2005, p. 495) research suggested that 'listed companies offer more attributional explanations on a wider range of accounting outcomes, although these are not more extensive or profound." They also observed that "listed companies exhibited a higher degree of defensiveness in explaining negative accounting outcomes" (Aerts, 2005 p. 514). Interestingly, the moderate degree of attributional defensiveness, in comparison with previous research that used US data, pointed to potentially significant cultural influences on the explanation patterns displayed by companies from different countries (Aerts, 2005).

All the previous studies discussed so far documented the asymmetry in the attribution of causality in performance related attributions. However, the theoretical bases from which researchers try to detect and interpret this empirical regularity vary, as well as the results.

\section{HYPOTHESES DEVELOPMENT}

Before formulating the hypotheses, it is necessary to clarify the terminology adopted in this work.

The two major segments of the São Paulo Stock Exchange are used here as proxies for corporate governance levels. A categorical variable is coded as 0 for the traditional market segment and as 1 for the differentiated market segment.

The positive effects referred to in the above items are denominated good news in the present work. Facts like higher profits, lower losses or increasing revenues are examples of such effects.

The negative effects are denominated bad news in the present work. Facts like lower profits, higher losses or decreasing revenues are examples of such effects.

Internal causes are those resulting from, among others, greater efforts, ingenuity, competence, skillfulness, effectiveness or capacity on the part of managers or the company.

External causes are those resulting from events like natural disasters, government interference, foreign exchange conditions or inflation, all of which are beyond control of managers or the company.

Self-serving attributions are identified every time good news is attributed to internal causes or bad news is attributed to external causes. Attributions of good news to external causes or bad news to internal causes do not qualify as self-serving attributions.

The firt hypothesis, applied on three different subsets of data, concerns whether or not self-serving attributions are to be found in the sample.

Hypothesis 1a: In the sample as a whole, differences between the observed frequency (number) and expected frequency (number) in the associations of effects (bad or good news) and causes (external or internal) are not due merely to chance.

Hypothesis 1b: In the traditional market portion of the sample, differences between the observed frequency (number) and expected frequency (number) in the associations of effects (bad or good news) and causes (external or internal) are not due merely to chance. 
Hypothesis 1c: In the differentiated market portion of the sample, differences between the observed frequency (number) and expected frequency (number) in the associations of effects (bad or good news) and causes (external or internal) are not due merely to chance.

Hypothesis 2: Differences in the number of associations of effects (bad or good news) and causes (external or internal) between traditional market companies and differentiated market companies are not due merely to chance.

Hypothesis 3: Differences in the percentage of the report dedicated to each association of effects (bad or good news) and causes (external or internal) between traditional market companies and differentiated market companies are not due merely to chance.

\section{DATA AND METHOD}

Staw et al. (1983) pointed out that annual reports are adequate as sources of organizational data for studies concerning self-serving attributions. In the present work we investigate attributions concerning information about operational, economic or financial performance of the organizations, using the management report. Other aspects, such as social or environmental information, are not regarded here.

A total of 385 companies had management reports available at the Bovespa Internet site (www.bovespa.com.br) for 2006. We downloaded all 385 management reports from the site.

Next, we obtained information from the Bovespa site relative to what market segment each company belonged to. Of the 385 companies, 295 belonged to the traditional market ( $76.62 \%$ of the sample) and 90 belonged to the differentiated market (23.38\% of the sample).

We subjected the downloaded reports to content analysis techniques. The procedure involved parsing each report into its component sentences. Tables and drawings were disregarded. Once parsed, the sentences were coded according to the three criteria presented in Table 2. These criteria are adaptations of previous research on attributional patterns (Bettman \& Weitz, 1983; Staw et al., 1983; Tsang, 2002; Aerts, 2001, 2005).

Table 2 - Coding criteria

\begin{tabular}{lll}
\hline Criterion & Coding & Notes \\
\hline Sentence Codable or Not. & $\begin{array}{l}0=\text { Not codable. } \\
1=\text { Codable. }\end{array}$ & $\begin{array}{l}\text { Codable means that the sentence refers to } \\
\text { kind of news regarding a company's operational, } \\
\text { economic or financial performance and a cause } \\
\text { can be identified for the effect. }\end{array}$ \\
\hline Bad or Good News. & $\begin{array}{l}0=\text { Bad news. } \\
1=\text { Good news. }\end{array}$ & $\begin{array}{l}\text { The type of effect shown by the sentence: positive } \\
\text { or negative. }\end{array}$ \\
\hline External or Internal Causes. & $0=$ External. & $\begin{array}{l}\text { Whether the causes are attributed to factors } \\
\text { external or internal to the company. }\end{array}$ \\
\hline
\end{tabular}

After coding, we counted the sentences in each report, according to the following definitions:

- Counting the total number of sentences present in the report, whether or not codable;

- Counting the number of sentences considered codable in the report (i.e., sentences where attributions were identified). This count was used basically for check-sum purposes, since it should always equal the sum of the four other counts below;

- Counting the number of sentences attributing "bad news" to external causes, which is usually considered a self-serving attribution;

- Counting the number of sentences attributing "bad news" to internal causes;

- Counting the number of sentences attributing "good news" to external causes; 
- Counting the number of sentences attributing "good news" to internal causes, which is usually considered a self-serving attribution;

We then calculated a number of variables, using these counts. The results of these procedures provided the database, containing for each report, and hence for each company, the information described in Table 3.

Table 3 - Database contents

\begin{tabular}{ll}
\hline Variable & Description \\
\hline $\mathbf{c i}$ & Company identification code. \\
\hline $\mathbf{b s}$ & Bovespa seal (0 = Traditional Market; 1 = Differentiated Market). \\
\hline $\mathbf{y r}$ & Year of the report (always 2006). \\
\hline $\mathbf{n s r}$ & Total number of sentences in the report. \\
\hline $\mathbf{b e}$ & Number of sentences where attributions were identified. \\
\hline $\mathbf{b i}$ & $\begin{array}{l}\text { Number of sentences attributing "bad news" to external causes (considered a self-serving } \\
\text { attribution). }\end{array}$ \\
\hline ge & $\begin{array}{l}\text { Number of sentences attributing "bad news" to internal causes (NOT considered a self-serving } \\
\text { attribution). }\end{array}$ \\
\hline bi & $\begin{array}{l}\text { Number of sentences attributing "good news" to external causes (NOT considered a self-serving } \\
\text { attribution). }\end{array}$ \\
\hline pbe & $\begin{array}{l}\text { Number of sentences attributing "good news" to internal causes (considered a self-serving } \\
\text { attribution). }\end{array}$ \\
\hline pbi & $\begin{array}{l}\text { Percentage of sentences in the report dedicated to associations of "bad news" and external causes, } \\
\text { expressed in decimal form (pbe = be /nsr). }\end{array}$ \\
\hline pge & $\begin{array}{l}\text { Percentage of sentences in the report dedicated to associations of "bad news" and internal causes, } \\
\text { expressed in decimal form (pbi = bi / nsr). }\end{array}$ \\
\hline Percentage of sentences in the report dedicated to associations of "good news" and external causes, \\
expressed in decimal form (pge = ge /nsr).
\end{tabular}




\section{RESULTS}

Table 4 presents the descriptive statistics for the whole sample.

Table 4 - Descriptive statistics

\begin{tabular}{lllllll}
\hline \multicolumn{2}{l}{ Whole sample } & & & & \\
\hline Variable & Obs & Count & Mean & Std. Dev. & Min. & Max. \\
\hline nsr & 385 & 47,565 & 123.5 & 143.9 & 3 & 986 \\
ndc & 385 & 1,257 & 3.3 & 3.2 & 0 & 22 \\
be & 385 & 268 & 0.7 & 1.2 & 0 & 8 \\
bi & 385 & 138 & 0.4 & 0.8 & 0 & 5 \\
ge & 385 & 128 & 0.3 & 0.8 & 0 & 5 \\
gi & 385 & 723 & 1.9 & 2.2 & 0 & 13 \\
pbe & 385 & na & 0.0095 & 0.0223 & 0.0000 & 0.2000 \\
pbi & 385 & na & 0.0049 & 0.0167 & 0.0000 & 0.2000 \\
pge & 385 & na & 0.0033 & 0.0087 & 0.0000 & 0.0556 \\
pgi & 385 & na & 0.0197 & 0.0251 & 0.0000 & 0.1667 \\
psc & 385 & na & 0.0375 & 0.0427 & 0.0000 & 0.4000 \\
\hline na: not applicable & & & & &
\end{tabular}

na: not applicable

Table 5 presents the descriptive statistics for the traditional market portion of the sample.

Table 5 - Descriptive statistics

\begin{tabular}{|c|c|c|c|c|c|c|}
\hline Variable & Obs & Count & Mean & Std. Dev. & Min. & Max. \\
\hline nsr & 295 & 27,551 & 93.4 & 113.2 & 3 & 852 \\
\hline nsc & 295 & 801 & 2.7 & 2.7 & 0 & 17 \\
\hline be & 295 & 187 & 0.6 & 1.1 & 0 & 6 \\
\hline bi & 295 & 84 & 0.3 & 0.7 & 0 & 5 \\
\hline ge & 295 & 84 & 0.3 & 0.7 & 0 & 4 \\
\hline gi & 295 & 446 & 1.5 & 1.8 & 0 & 10 \\
\hline pbe & 295 & na & 0.0107 & 0.0245 & 0.0000 & 0.2000 \\
\hline pbi & 295 & na & 0.0053 & 0.0186 & 0.0000 & 0.2000 \\
\hline pge & 295 & na & 0.0035 & 0.0095 & 0.0000 & 0.0556 \\
\hline pgi & 295 & na & 0.0203 & 0.0269 & 0.0000 & 0.1667 \\
\hline psc & 295 & na & 0.0398 & 0.0461 & 0.0000 & 0.4000 \\
\hline
\end{tabular}

Table 6 presents the descriptive statistics for the differentiated market portion of the sample. 
Table 6 - Descriptive statistics

\begin{tabular}{lllllll}
\hline \multicolumn{7}{l}{ Differentiated Market $(\mathbf{b s}=\mathbf{1}), \mathbf{2 3 . 3 8 \%}$} \\
\hline Variable & Obs & Count & Mean & Std. Dev. & Min. & Max. \\
\hline nsr & 90 & 20,014 & 222.4 & 184.9 & 8 & 986 \\
nsc & 90 & 456 & 5.1 & 4.1 & 0 & 22 \\
be & 90 & 81 & 0.9 & 1.5 & 0 & 8 \\
bi & 90 & 54 & 0.6 & 1.0 & 0 & 5 \\
ge & 90 & 44 & 0.5 & 1.0 & 0 & 5 \\
gi & 90 & 277 & 3.1 & 2.8 & 0 & 13 \\
pbe & 90 & na & 0.0056 & 0.0117 & 0.0000 & 0.0659 \\
pbi & 90 & na & 0.0038 & 0.0075 & 0.0000 & 0.0349 \\
pge & 90 & na & 0.0026 & 0.0055 & 0.0000 & 0.0227 \\
pgi & 90 & na & 0.0178 & 0.0181 & 0.0000 & 0.0741 \\
psc & 90 & na & 0.0297 & 0.0273 & 0.0000 & 0.1163 \\
\hline na: not applicable & & & & &
\end{tabular}

An observation in the descriptive statistics draws immediate attention. The mean report length $(n s r)$ for traditional market companies is 93.4 sentences per report. For differentiated market companies the mean report length is 222.4 sentences per report, or roughly 2.4 times greater. This and the average number of coded sentences per report (nsc) and the average counts of each attributional instance (be, bi, ge, gi) for each group of companies can be examined in Table 7 .

Table 7 - Comparison of average sentences per report

\begin{tabular}{lllllll}
\hline Companies & $\begin{array}{l}\text { Average } \\
\text { nsr }\end{array}$ & $\begin{array}{l}\text { Average } \\
\text { nsc }\end{array}$ & $\begin{array}{l}\text { Average } \\
\text { be }\end{array}$ & $\begin{array}{l}\text { Average } \\
\text { bi }\end{array}$ & \multicolumn{2}{c}{ Average Average } \\
& 93.4 & 2.7 & 0.6 & 0.3 & 0.3 & gi \\
\hline Traditional & 222.4 & 5.1 & 0.9 & 0.6 & 0.5 & 3.5 \\
Differentiated & 2.4 & 1.9 & 1.5 & 2.0 & 1.7 & 2.1 \\
\hline Diff/Trad & & & & &
\end{tabular}

As can be seen, the averages for differentiated market companies hover consistently in the neighborhood of twice those for traditional market companies. In order to further investigate this issue, we ran two OLS linear regressions. The results for the one comparing the number of sentences coded for attributions ( $n s c$ ) against the total number of sentences in the report (nsr) are given in Table 8.

\section{Table 8 - OLS regression $(\mathrm{nsc}=\mathrm{B} 0+\mathrm{B} 1 . \mathrm{nsr}+\mathrm{e})$}

\begin{tabular}{lllll} 
& Coef & Std. Err & $\mathbf{t}$ & $\mathbf{P}>|\mathbf{t}|$ \\
\hline nsr & 0.0115 & 0.0010 & 11.65 & 0.0000 \\
const & 1.8497 & 0.1864 & 9.92 & 0.0000 \\
\hline Obs & $\mathbf{F}(\mathbf{1 , 3 8 3})$ & Prob>F & $\mathbf{R 2}$ & Adj R2 \\
\hline 385 & 135.68 & $0.0000^{* * *}$ & 0.2616 & 0.2597 \\
\hline
\end{tabular}

The results for the other regression, comparing the percentage of the report taken up by coded sentences ( $p s c$ ) against the total number of sentences in the report ( $n s r)$ are given in Table 9. 
Table 9- OLS regression $(\mathrm{psc}=\mathrm{BO}+\mathrm{B1} . \mathrm{nsr}+\mathrm{e})$

\begin{tabular}{lllll}
\hline & Coef & Std. Err & $\mathbf{t}$ & $\mathbf{P}>|\mathbf{t}|$ \\
\hline nsr & -0.0001 & 0.0000 & -4.47 & 0.0000 \\
const & 0.0456 & 0.0028 & 16.30 & 0.0000 \\
\hline Obs & $\mathbf{F}(\mathbf{1 , 3 8 3})$ & Prob $>\mathbf{F}$ & $\mathbf{R 2}$ & Adj R2 \\
\hline 385 & 19.98 & $0.0000^{* * * *}$ & 0.0496 & 0.0471 \\
\hline
\end{tabular}

Both regressions, as well as the respective variables, are significant at $1 \%$. But taken together they tell different stories. The first one shows that for every additional sentence in the report, one can expect a continuous increase of 0.0115 coded sentences. In other words, for about every 87 additional sentences in a report it can be expected that one more sentence will be the subject of coding. The second regression, in turn, indicates that the same additional 87 sentences would bring about a decrease of 0.0087 ( 0.87 percentage points) in occupation of the report with codable attributions (falling from $3.00 \%$ to $2.13 \%$, for example). These regressions together seemingly indicate that even though the count of codable attributions rises with report size, the percentage of the report dedicated to these attributions actually falls as size increases.

\subsection{Testing hypotheses $1 \mathrm{a}, 1 \mathrm{~b}$ and $1 \mathrm{c}$}

We tested hypothesis 1a, concerning the whole sample, by arranging the pertinent data in a 2 x 2 contingency table and using a chi ${ }^{2}$ test. The data and results are shown in Table 10. Self-serving attributions are shaded grey.

Table 10 - Hypothesis 1a - Whole sample

\begin{tabular}{|c|c|c|c|c|}
\hline & & $\begin{array}{l}\text { External } \\
\text { Causes }\end{array}$ & $\begin{array}{l}\text { Internal } \\
\text { Causes }\end{array}$ & Total \\
\hline Bad News & $\begin{array}{l}\text { Frequency } \\
\text { Expected } \\
\text { Cell \% } \\
\text { Row \% } \\
\text { Column \% }\end{array}$ & $\begin{array}{l}\mathbf{2 6 8} \\
127.9 \\
21.32 \% \\
66.01 \% \\
67.68 \%\end{array}$ & $\begin{array}{l}\mathbf{1 3 8} \\
278.1 \\
10.98 \% \\
33.99 \% \\
16.03 \%\end{array}$ & $\begin{array}{l}406 \\
32.30 \%\end{array}$ \\
\hline Good News & $\begin{array}{l}\text { Frequency } \\
\text { Expected } \\
\text { Cell \% } \\
\text { Row \% } \\
\text { Column \% }\end{array}$ & $\begin{array}{l}\mathbf{1 2 8} \\
268.1 \\
10.18 \% \\
15.04 \% \\
32.32 \%\end{array}$ & $\begin{array}{l}\mathbf{7 2 3} \\
582.9 \\
57.52 \% \\
84.96 \% \\
83.97 \%\end{array}$ & $\begin{array}{l}851 \\
67.70 \%\end{array}$ \\
\hline Total & & $\begin{array}{l}396 \\
31.50 \%\end{array}$ & $\begin{array}{l}861 \\
68.50 \%\end{array}$ & $\begin{array}{l}1,257 \\
100.00 \%\end{array}$ \\
\hline $\mathrm{sl}=\mathbf{0 . 0 1}$ & df & Critical & Value & $\mathbf{p}$ \\
\hline Pearson Chi ${ }^{2}$ & 1 & 6.6349 & 330.9025 & 0.0000 \\
\hline
\end{tabular}

The results show that self-serving attributions do occur in the sample as a whole, and are not due merely to chance $\left(\mathrm{pchi}^{2}[1]<0.01\right)$. The prevailing variable associations are, by and large, those defined as representing self-serving attributions, and the differences between observed and expected frequencies are not random occurrences. The bad/external association 
represents $21.32 \%$ of all associations, while good/internal represents $57.52 \%$ of them. These associations are also prevalent when row and column percentages are considered.

We tested hypothesis $1 \mathrm{~b}$, concerning the traditional market portion of the sample, using the same procedure. The data and results are shown in Table 11.

Table 11 - Hypothesis 1b - Traditional Market

\begin{tabular}{|c|c|c|c|c|}
\hline & & $\begin{array}{c}\text { External } \\
\text { Causes }\end{array}$ & $\begin{array}{c}\text { Internal } \\
\text { Causes }\end{array}$ & Total \\
\hline Bad News & \begin{tabular}{|l|} 
Frequency \\
Expected \\
Cell \% \\
Row \% \\
Column \% \\
\end{tabular} & \begin{tabular}{l}
\multicolumn{1}{c}{$\mathbf{1 8 7}$} \\
91.7 \\
$23.35 \%$ \\
$69.00 \%$ \\
$69.00 \%$
\end{tabular} & \begin{tabular}{|l|}
$\mathbf{8 4}$ \\
179.3 \\
$10.49 \%$ \\
$31.00 \%$ \\
$15.85 \%$
\end{tabular} & $\begin{array}{r}271 \\
33.83 \%\end{array}$ \\
\hline Good News & \begin{tabular}{|l} 
Frequency \\
Expected \\
Cell \% \\
Row \% \\
Column \%
\end{tabular} & $\begin{array}{l}\mathbf{8 4} \\
179.3 \\
10.49 \% \\
15.85 \% \\
31.00 \%\end{array}$ & $\begin{array}{l}446 \\
350.7 \\
55.68 \% \\
84.15 \% \\
84.15 \%\end{array}$ & $\begin{array}{l}530 \\
66.17 \%\end{array}$ \\
\hline Total & & $\begin{array}{l}271 \\
33.83 \%\end{array}$ & $\begin{array}{l}530 \\
66.17 \%\end{array}$ & $\begin{array}{l}801 \\
100.00 \%\end{array}$ \\
\hline $\mathrm{ns}=\mathbf{0 . 0 1}$ & DF & Critical & Value & $\mathbf{p}$ \\
\hline Pearson Chi ${ }^{2}$ & 1 & 6.6349 & 226.3157 & 0.0000 \\
\hline
\end{tabular}

The results are overall similar to those of hypothesis 1a. Self-serving attributions also occur in the traditional market portion of the sample and are not due to chance $\left(\right.$ pchi $^{2}[1]<$ $0.01)$. The bad/external association represents $23.35 \%$ of all associations, while good/internal represents $55.68 \%$ of them. These associations are also prevalent when row and column percentages are considered.

We tested hypothesis 1c, concerning the differentiated market portion of the sample, the same way as the previous two hypotheses. The data and results are shown in Table 12.

Table 12 - Hypothesis 1c - Differentiated Market

\begin{tabular}{|c|c|c|c|c|}
\hline & & \begin{tabular}{|l|} 
External \\
Causes
\end{tabular} & \begin{tabular}{|l} 
Internal \\
Causes
\end{tabular} & Total \\
\hline Bad News & \begin{tabular}{|l} 
Frequency \\
Expected \\
Cell \% \\
Row \% \\
Column \% \\
\end{tabular} & $\begin{array}{l}81 \\
37.0 \\
17.76 \% \\
60.00 \% \\
64.80 \% \\
\end{array}$ & $\begin{array}{l}54 \\
98.0 \\
11.84 \% \\
40.00 \% \\
16.31 \% \\
\end{array}$ & $\begin{array}{l}135 \\
29.61 \%\end{array}$ \\
\hline Good News & \begin{tabular}{|l} 
Frequency \\
Expected \\
Cell \% \\
Row \% \\
Column \%
\end{tabular} & $\begin{array}{l}44 \\
88.0 \\
9.65 \% \\
13.71 \% \\
35.20 \%\end{array}$ & $\begin{array}{l}277 \\
233.0 \\
60.75 \% \\
86.29 \% \\
83.69 \%\end{array}$ & $\begin{array}{l}321 \\
70.39 \%\end{array}$ \\
\hline Total & & $\begin{array}{l}125 \\
27.41 \%\end{array}$ & $\begin{array}{l}331 \\
72.59 \%\end{array}$ & $\begin{array}{l}456 \\
100.00 \%\end{array}$ \\
\hline ns $=0.01$ & df & Critical & Value & $\mathbf{p}$ \\
\hline Pearson $\mathrm{Chi}^{2}$ & 1 & 6.6349 & 102.3513 & 0.0000 \\
\hline
\end{tabular}


The results are also equivalent to those found for hypotheses 1a and 1b. Self-serving attributions are also prevalent in the differentiated market portion of the sample and not due to chance $\left(\mathrm{pchi}^{2}[1]<0.01\right)$. The bad/external association represents $17.76 \%$ of all associations, while good/internal represents $60.75 \%$ of them. These associations are also prevalent when row and column percentages are considered.

Taken together, the results of the tests for the three hypotheses show that companies in the sample use self-serving attributions in their reports, regardless of the corporate governance seal given to them by the Bovespa.

\subsection{Testing hypothesis 2}

We tested hypothesis 2, concerning whether the number of attributions in reports of companies in the differentiated market segment is different of that found in reports of traditional market companies, using a logit regression model. The model compared the categorical variable $b s$, which represents whether the company belongs to the traditional or differentiated market, with the variables $b e, b i$, ge and $g i$, which contain counts for associations. The results are shown in Table 13.

Table 13 - Logit regression - Results

\begin{tabular}{|c|c|c|c|c|}
\hline $\mathbf{y}=$ & Bs & & & \\
\hline Variable $x_{n}$ & Odds Ratio & Std. Err. & $\mathbf{z}$ & $\mathbf{P}>|\mathbf{z}|$ \\
\hline $\mathbf{B e}$ & 1.1620 & 0.1181 & 1.48 & 0.1400 \\
\hline $\mathbf{B i}$ & 1.3170 & 0.1924 & 1.88 & 0.0590 \\
\hline Ge & 0.9313 & 0.1650 & -0.40 & 0.6880 \\
\hline Gi & 1.3427 & 0.0805 & 4.91 & 0.0000 \\
\hline \multicolumn{5}{|c|}{ Base category is bs = 0 (Traditional Market) } \\
\hline Obs & 385 & & & \\
\hline $\operatorname{LR} \operatorname{chi}^{2}(4)=$ & 38.96 & & & \\
\hline Prob $>$ chi $^{2}=$ & 0.0000 & \multicolumn{3}{|c|}{$* * *$} \\
\hline Pseudo $\mathbf{R}^{2}=$ & 0.0931 & & & \\
\hline
\end{tabular}

The regression's results show that the model is significant at $1 \%$, but only variables $b i$ and $g i$ are significantly different between companies belonging to the differentiated market and those at the traditional market. The interpretation is that companies which have better corporate governance show a 34\% greater chance of attributing good news to internal causes (and paradoxically, though less significantly, of attributing bad news also to internal causes). The results can also be interpreted as showing that higher counts of the association good news/internal causes, the self-serving pattern, are 34\% more likely to be found among companies belonging to the differentiated market. This is somewhat surprising, as it contradicts a perhaps naïve supposition that companies with better corporate governance are more neutral in the analysis of their own performance.

\subsection{Testing hypothesis 3}

We tested hypothesis 3 , concerning whether differences can be found between the two groups of companies regarding the percentage of the reports dedicated to each attributional instance, also using a logit regression model. We compared the categorical variable $b s$ with 
the variables $p b e, p b i$, pge and $p g i$, which represent the percentage of the reports dedicated to each association. The results are shown in Table 14.

Table 14 - Logit regression - Results

\begin{tabular}{lllll}
\hline $\mathbf{y}=$ & Bs & & \\
\hline Variable $\mathbf{x}_{\mathbf{n}}$ & Odds Ratio & Std. Err. & $\mathbf{z}$ & $\mathbf{P}>|\mathbf{z}|$ \\
\hline Pbe & 0.0000 & 0.0000 & -1.82 & 0.0690 \\
Pbi & 0.0808 & 0.8116 & -0.25 & 0.8020 \\
Pge & 0.0000 & 0.0000 & -0.82 & 0.4120 \\
Pgi & 0.0208 & 0.1077 & -0.75 & 0.4550 \\
\hline Base category is bs $=\mathbf{0}$ (Traditional Market) & & \\
\hline Obs $=$ & 385 & & & \\
\hline LR chi ${ }^{\mathbf{2}} \mathbf{( 4 )}=$ & 6.26 & & & \\
\hline Prob $>\mathbf{c h i}^{\mathbf{2}}=$ & 0.1808 \\
\hline Pseudo $\mathbf{R}^{\mathbf{2}}=$ & 0.0149 \\
\hline
\end{tabular}

These results show that the model is not significant (prob $>\mathrm{chi}^{2}=0.1808$ ), and no significant differences are found between companies belonging to either group. As observed in the descriptive statistics section, reports from differentiated market companies are on average lengthier than those of traditional market companies, and this fact could be an explanation why hypothesis 2 tested positive while hypothesis 3 tested negative: a higher number of attributions for differentiated market companies is only the outcome of their lengthier reports. The fact that hypothesis 3 tested negative corroborates this interpretation.

\section{CONCLUSION}

The present work investigates the theoretical linkage between corporate governance levels, as denoted by the Bovespa differentiated market seal, and causal attributions in the narrative section of annual reports. Its conclusions are limited to the sample analyzed.

The results confirm the use of self-serving attributions in annual reports, as previously pointed out by many other works, regardless of the corporate governance level indicated by the Bovespa seal. The number of sentences containing causal attributions initially indicated a possible relationship between good news attributed to internal causes and companies with higher levels of corporate governance. These companies apparently used that particular instance of self-serving attributions more extensively than companies positioned at lower levels of corporate governance. This finding is somewhat surprising. The expectation is that due to the demands for sincerity and transparency posed by precepts of better corporate governance practices, companies possessing the Bovespa seal for commitment to these better practices should act more humbly and avoid resorting to self-serving attributions. Further investigation, using the percentage of the total sentences in the report dedicated to each instance of the causal attributions chosen for study, showed no apparent relationship. This led to a possible explanation involving the length of the reports. Reports from companies in the differentiated market portion of the sample were on average longer than those of companies in the traditional market segment. Higher numbers of causal attributions should be expected in lengthier reports. So, no conclusive evidence supporting a relationship between causal attributions and the Bovespa corporate governance levels was found. 
Future works in this line of investigation should address a number of additional points and make methodological refinements. Reports of other years could be used to investigate whether the results obtained hold up in a time series. Other variables, such as company size, equity control and industry segment, could be added to the models, trying to clarify the role played by causal attributions in connection with corporate governance. Other statistical tools and methods, such as factor analysis, could also be applied.

\section{REFERENCES}

AERTS, W. (1994) On the use of accounting logic as an explanatory category in narrative accounting disclosures. Accounting, Organizations and Society, 19, (4/5), p. 337-53.

AERTS, W. (2001) Inertia in the attributional content of annual accounting narratives. The European Accounting Review, 10, (1), pp. 3-32.

AERTS, W. (2005) Picking up the pieces: impression management in the retrospective attributional framing of accounting outcomes. Accounting, Organizations and Society, 30, pp. 493-517.

BETTMAN, J. R.; WEITZ, B. A. (1983) Attributions in the boardroom: Causal reasoning in corporate annual reports. Administrative Science Quarterly, 28 (2), pp. 165-183.

CLAPHAM, S. E.; SCHWENK, C. R. (1991) Self-serving attributions, managerial cognition, and company performance. Strategic Management Journal, 12, (3), pp. 219-229.

CLATWORTHY, M. A.; JONES, M. J. (2003) Financial reporting of good and bad news: Evidence from accounting narratives, Accounting and Business Research, 33, (3), pp. 17185 .

GALDI, F. C.; LOPES, A. B. (2007) Does Financial Statement Analysis Generate Abnormal Returns under Extremely Adverse Conditions? In: American Accounting Association (AAA) Meeting, 2007, Chicago, IL. AAA 2007 annual meeting, 2007

HUFF, A.S., SCHWENK, C. (1990), Bias and sense making in good times and bad. In HUFF, A.S. (Eds), Mapping Strategic Thought, John Wiley, Chichester, pp.49-108.

IMHOFF, E. A. (2003) Accounting quality, auditing and corporate governance. Accounting Horizons (Supplement), pp. 117-128.

INSTITUTO BRASILEIRO DE GOVERNANÇA CORPORATIVA (IBGC) (2004). Código das melhores práticas de governança corporativa. 3rd ed. São Paulo.

JENSEN, M. C.; MECKLING, W. H. (1976) Theory of the firm: Managerial behaviour, agency costs and ownership structure. Journal of Financial Economics, 3, pp. 305-360.

KELlEY, H. H. (1971) The process of causal attribution. American Psichologist, 28, pp. 107-28.

LOPES, A. B. (2008) The relation between firm-specific corporate governance, crosslisting and the informativeness of accounting numbers in Brazil. 2008. $200 \mathrm{f}$. Unpublished PhD Dissertation - Manchester Business School, University of Manchester, Manchester.

LOPES, A. B.; MARTINS, E. (2005) Teoria da contabilidade: uma nova abordagem. São Paulo: Atlas.

MILLER, D. T.; ROSS, M. (1975) Self-serving biases in the attribution of causality: Fact or fiction? Psychological Bulletin, 82, pp. 213-225. 
SALANCIK, G. R.; MENDL, J. R. (1984) Corporate attributions as strategic illusions of management control, Administrative Science Quarterly, 29,(2), pp. 238-254.

SCHLENKER, B.R. (1980). Impression Management: The self-concept, social identity, and interpersonal relations. Monterey, CA: Brooks/Cole.

STAW, B. M. (1980) Rationality and justification in organizational life. In: STAW, B.M. \& CUMMINGS, L. L. Research in Organizational Behavior, 2, pp. 45-80.

STAW, B.M.; MCKECHNIE, P.I.; PUFFER, S. M. (1983) The justification of organizational performance, Administrative Science Quarterly, 28, pp. 582-600.

SHLEIFER, A.; VISHNY, R. (1997) A survey of corporate governance. Journal of Finance 52, (2), pp. 737-783.

STAW, B.M.; MCKECHNIE, P.I.; PUFFER, S. M. (1983) The justification of organizational performance. Administrative Science Quarterly, 28, pp. 582-600.

TSANG, E. W. K. (2002) Self-serving attributions in corporate annual reports: A replicated study. Journal of Management Studies, 39, (1), pp. 51-65. 